\title{
Quality of pre-sprouted sugarcane seedlings grown on substrates with decomposed babassu palm stem ${ }^{1}$
}

\author{
Romário Martins Costa ${ }^{2}$, Marcos Renan Lima Leite², Sâmia dos Santos Matos², \\ Rayssa Carolinne Mouzinho de Sousa ${ }^{2}$, Raissa Rachel Salustriano da Silva-Matos ${ }^{3}$, Antônio Aécio de Carvalho Bezerra ${ }^{4}$
}

\section{ABSTRACT}

The use of pre-sprouted seedlings in the implantation of sugarcane crops not only reduces the establishment period and production costs, but also has other advantages, such as a lesser requirement of propagules (stems) and greater phytosanitary control of the seedlings, when compared to conventional planting. Commercial substrates are also expensive and their use increases the cost of seedlings. This study aimed to evaluate the quality of sugarcane pre-sprouted seedlings grown on substrates with different proportions of decomposed babassu palm stem (DBPS), as well as to recommend the substrate formulation that provides the most favorable environment for the growth and development of sugarcane pre-sprouted seedlings. For preparation of the substrate (S), DBPS and soil were used in the following proportions: S1: $0 \%$ of DBPS $+100 \%$ of soil; S2: $20 \%$ of DBPS $+80 \%$ of soil; S3: $40 \%$ of DBPS $+60 \%$ of soil; S4: $60 \%$ of DBPS + $40 \%$ of soil; S5: $80 \%$ of DBPS + $20 \%$ of soil; S6: $100 \%$ of DBPS $+0 \%$ of soil. The use of S2 and $\mathrm{S} 3$ considerably improved the seedling quality parameters, such as sprout diameter and length, number of leaves and total, shoot and root dry mass. However, from an economic point of view, $\mathrm{S} 2$ is recommended for use.

KEYWORDS: Saccharum officinarum L., Attalea speciosa Mart. ex Spreng, alternative substrate, seedling production.

\section{INTRODUCTION}

Sugarcane (Saccharum officinarum L.), a member of the Poaceae family, is a grass of great socioeconomic importance grown in tropical and subtropical regions worldwide and used as a raw material for the production of sugar and alcohol, as it stores high concentrations of sucrose in its stem

\section{RESUMO}

Qualidade de mudas pré-brotadas de cana-de-açúcar cultivadas em substratos com caule decomposto de babaçu

A utilização de mudas pré-brotadas na implantação de lavouras de cana-de-açúcar não só reduz o período de implantação e os custos de produção, mas, também, traz outras vantagens, como menor necessidade de propágulos (colmos) e maior controle fitossanitário das mudas, em comparação ao plantio convencional. Os substratos comerciais também são caros e seu uso aumenta o custo das mudas. Objetivou-se avaliar a qualidade de mudas prébrotadas de cana-de-açúcar cultivada em substratos com diferentes proporções de caule decomposto de palmeira de babaçu (CDPB), bem como recomendar a formulação do substrato que proporciona o ambiente mais favorável para o crescimento e desenvolvimento de mudas pré-brotadas de cana-de-açúcar. Para a preparação do substrato (S), CDPB e solo foram usados nas seguintes proporções: S1: $0 \%$ de CDPB + $100 \%$ de solo; S2: $20 \%$ de CDPB + $80 \%$ de solo; S3: $40 \%$ de CDPB + $60 \%$ de solo; S4: $60 \%$ de CDPB + $40 \%$ de solo; S5: $80 \%$ de CDPB + $20 \%$ de solo; S6: $100 \%$ de CDPB + $0 \%$ de solo. O uso de S2 e S3 melhorou consideravelmente os parâmetros de qualidade das mudas, como diâmetro e comprimento do broto, número de folhas e massa seca total, da parte aérea e da raiz. No entanto, do ponto de vista econômico, indica-se o substrato S2.

PALAVRAS-CHAVE: Saccharum officinarum L., Attalea speciosa Mart. ex Spreng, substrato alternativo, produção de mudas.

(Martini et al. 2020). Brazil is the world's largest producer of sugarcane. In the 2019-2020 crop season, it achieved a production of 642.7 million tons, with a harvested area of 8.4 million hectares and average yield of $76.5 \mathrm{t} \mathrm{ha}^{-1}$ (Conab 2020).

The conventional mechanized planting of sugarcane requires a quantity of more than $20 \mathrm{tha}^{-1}$ of propagules (stems) (May \& Ramos 2019) and accounts

${ }^{1}$ Received: Nov. 11, 2020. Accepted: Feb. 22, 2021. Published: Mar. 16, 2021. DOI: 10.1590/1983-40632021v5166587.

${ }^{2}$ Universidade Federal do Piauí, Centro de Ciências Agrárias, Teresina, PI, Brasil.

E-mail/ORCID: romario.martins90@hotmail.com/0000-0001-5429-4663; marcos_lleite@hotmail.com/0000-0002-2910-9232; samiamatos2011@hotmail.com/0000-0002-4573-9277; rayssa.mouzinho@gmail.com/0000-0002-1478-872X.

${ }^{3}$ Universidade Federal do Maranhão, Centro de Ciências Agrárias, Chapadinha, MA, Brasil.

E-mail/ORCID: raissasalustriano@yahoo.com.br/0000-0002-8908-2297.

${ }^{4}$ Universidade Federal do Piaú, Centro de Ciências Agrárias, Departamento de Planejamento e Política Agrícola, Teresina, PI, Brasil. E-mail/ORCID: aecio@ufpi.edu.br/0000-0001-7681-6426. 
for more than $20 \%$ of the total production costs (Jain et al.2010). Additionally, the mechanized planting system may lead to uneven plant stands due to the competition among the tillers in the establishment phase (Aquino et al. 2018). In contrast, the use of pre-sprouted seedlings not only reduces the establishment period of the plants in the field and production costs (Landell et al. 2012), but also has other advantages, such as a significantly lesser requirement of stems owing to increased use of propagules, greater phytosanitary control of seedlings, and greater uniformity of plants, when compared to conventional planting.

For the production of quality seedlings, it is necessary to use substrates with good physical and chemical characteristics (Santos et al. 2020, Silva et al. 2020). According to Silva et al. (2016), several substrates, including commercial substrates, may be used for the production of pre-sprouted seedlings; however, these are costly and make the production process more expensive. Therefore, alternative substrates that offer good development conditions to seedlings, are low in cost, and reduce environmental impacts need to be adopted (Andrade et al. 2017, Cordeiro et al. 2018).

Decomposed babassu palm (Attalea speciosa Mart. ex Spreng, a plant abundant in the Brazilian Northeast) stem can be used in the formulation of alternative substrates. A substrate containing high proportions of decomposed babassu palm stem (DBPS) can provide higher concentrations of nutrients such as $\mathrm{N}, \mathrm{K}, \mathrm{Mg}$ and $\mathrm{S}$, in addition to greater porosity, than commercial substrates (Cordeiro et al. 2019). Some studies have shown the potential of DBPS in the production of melon seedlings (Cordeiro et al. 2018), passion fruit (Cordeiro et al. 2019) and watermelon (Andrade et al. 2017). However, studies are yet to be conducted using DBPS as a raw material in the composition of substrates for the production of pre-sprouted sugarcane seedlings. According to Macan et al. (2020), the use of pre-sprouted sugarcane seedlings is still a recent technology, with little research on seedling growth and development in the early stages.

Thus, this study aimed to evaluate the quality of pre-sprouted sugarcane seedlings grown on substrates with different proportions of DBPS, as well as to recommend the substrate formulation that provides the most favorable environment for the growth and development of pre-sprouted sugarcane seedlings.

\section{MATERIAL AND METHODS}

The experiment was conducted in a greenhouse, at the Universidade Federal do Maranhão, in Chapadinha, Maranhão state, Brazil (344'12.62"S, $43^{\circ} 19^{\prime} 03.51^{\prime}$ 'W and altitude of $105 \mathrm{~m}$ ), from September to October 2018.

A completely randomized design, with six treatments and five replications, was used. For the substrate (S) preparation, a dystrophic Yellow Latosol (LAd) (Santos et al. 2013) was removed from the $0-20 \mathrm{~cm}$ soil layer and mixed with decomposed babassu palm stem (DBPS) in the following proportions: S1: $0 \%$ of DBPS $+100 \%$ of soil $(0: 5$; $\mathrm{v} / \mathrm{v})$ (control); S2: $20 \%$ of DBPS $+80 \%$ of soil $(1: 4$ $\mathrm{v} / \mathrm{v}) ; \mathrm{S} 3: 40 \%$ of DBPS $+60 \%$ of $\operatorname{soil}(2: 3 ; \mathrm{v} / \mathrm{v}) ; \mathrm{S} 4$ : $60 \%$ of DBPS $+40 \%$ of soil $(3: 2 ; \mathrm{v} / \mathrm{v}) ; \mathrm{S} 5: 80 \%$ of DBPS $+20 \%$ of soil $(4: 1 ; \mathrm{v} / \mathrm{v})$; S6: $100 \%$ of DBPS $+0 \%$ of soil $(5: 0 ; \mathrm{v} / \mathrm{v})$. The babassu palm stem was harvested from the field already in the process of decomposition, watered weekly to speed up the decomposition process and used at 60 days after its collection in the field.

The substrates were physically characterized according to Schmitz et al. (2002), by evaluating the global and particle density, as well as total porosity (Table 1). The chemical analysis was performed according to Brasil (2007), by determining the $\mathrm{pH}$, electrical conductivity and the macronutrients nitrogen, phosphorus, potassium, calcium, magnesium and sulfur (Table 2).

The RB863129 sugarcane variety was used, which is harvested at 8 months of age from the first regrowth. The stem segments (mini-cuttings) were excised to a size of approximately $4 \mathrm{~cm}$, containing only one viable bud. For the seedling production,

Table 1. Physical analysis of substrates based on decomposed babassu palm stem (DBPS).

\begin{tabular}{cccc}
\hline \multirow{2}{*}{ Substrate $^{1}$} & \multicolumn{2}{c}{ Density $\left(\mathrm{g} \mathrm{cm}^{-3}\right)$} & \multirow{2}{*}{ Porosity $(\%)$} \\
\cline { 2 - 3 } & Global & Particle & \\
\hline S1 & 1.44 & 2.67 & 45.99 \\
S2 & 1.28 & 2.64 & 51.53 \\
S3 & 1.18 & 2.57 & 54.01 \\
S4 & 0.98 & 2.24 & 56.22 \\
S5 & 0.73 & 1.88 & 60.91 \\
S6 & 0.33 & 0.97 & 65.95 \\
\hline
\end{tabular}

'S1: $0 \%$ of DBPS $+100 \%$ of soil; S2: $20 \%$ of DBPS $+80 \%$ of soil; S3: $40 \%$ of DBPS $+60 \%$ of soil; S4: $60 \%$ of DBPS $+40 \%$ of soil; S5: $80 \%$ of DBPS + $20 \%$ of soil; S6: $100 \%$ of DBPS $+0 \%$ of soil. 
Table 2. Chemical analysis of substrates based on decomposed babassu palm stem (DBPS).

\begin{tabular}{|c|c|c|c|c|c|c|c|c|}
\hline Substrate $^{1}$ & $\mathrm{pH}$ & $\begin{array}{c}\mathrm{EC} \\
\mathrm{dS} \mathrm{m}^{-1}\end{array}$ & $\begin{array}{c}\mathrm{N} \\
\mathrm{g} \mathrm{kg}^{-1}\end{array}$ & $\begin{array}{c}\mathrm{P} \\
\mathrm{mg} \mathrm{kg}^{-1}\end{array}$ & K & $\begin{array}{r}\mathrm{Ca} \\
-\mathrm{cm} \\
\end{array}$ & $\mathrm{Mg}$ & $\mathrm{S}$ \\
\hline S1 & 4.00 & 0.10 & 0.63 & 13 & 0.67 & 0.8 & 0.3 & 1.5 \\
\hline S2 & 4.88 & 0.61 & 1.23 & 14 & 0.67 & 1.6 & 1.0 & 3.8 \\
\hline S3 & 5.11 & 1.36 & 1.46 & 13 & 1.82 & 3.2 & 1.7 & 7.6 \\
\hline $\mathrm{S} 4$ & 4.83 & 1.79 & 2.02 & 13 & 2.35 & 4.4 & 2.8 & 10.8 \\
\hline S5 & 5.16 & 3.00 & 3.47 & 27 & 6.17 & 10.9 & 4.6 & 24.6 \\
\hline S6 & 5.32 & 4.34 & 5.88 & 33 & 3.63 & 20.6 & 15.2 & 41.5 \\
\hline
\end{tabular}

${ }^{1}$ S1: $0 \%$ of DBPS $+100 \%$ of soil; S2: $20 \%$ of DBPS $+80 \%$ of soil; S3: $40 \%$ of DBPS $+60 \%$ of soil; S4: $60 \%$ of DBPS + $40 \%$ of soil; S5: $80 \%$ of DBPS + $20 \%$ of soil; S6: $100 \%$ of DBPS + $0 \%$ of soil.

only one mini-cutting per bag ( $150 \mathrm{~mL}$ capacity) was placed on the top layer of the substrate and covered with soil/substrate. The bags were placed on wooden benches in an area covered by black sombrite ${ }^{\mathrm{TM}}$ with $70 \%$ shade, where they were irrigated once a day to replace $100 \%$ of the seedling evapotranspiration, for 34 days.

The evaluation of sprouted seedlings (\%), that is, seedlings with leaves outside the substrate, was carried out at 7, 14, 21, 28 and 35 days after planting (DAP). At 35 DAP, evaluations of the following variables were performed: sprout diameter $(\mathrm{mm})$; sprout length $(\mathrm{cm}$; measured from the base of the bud to the tip of the leaf); root length $(\mathrm{cm})$; number of leaves; total, shoot and root dry mass (g). Rulers, with graduations in $\mathrm{mm}$, were used for measuring the shoot and root length, and a digital caliper for measuring the sprout diameter. For determining the shoot and root dry mass, fresh plant material was placed in an oven with forced air circulation at $60^{\circ} \mathrm{C}$, for 72 hours, and then weighed with a precision scale. The total dry mass was obtained from the sum of shoot dry mass and root dry mass.

The data were subjected to analysis of variance (Anova) by the F-test $(p<0.05)$ and the treatment means were compared using the ScottKnott test. The Pearson's correlation, at a minimum significance level of $5 \%$, was evaluated to study the relationship between the parameters. The analyses were performed using the Sisvar ${ }^{\mathrm{TM}}$ statistical software (Ferreira 2011) and subsequent graphs were plotted by the SigmaPlot ${ }^{\mathrm{TM}}$ 14.0.

\section{RESULTS AND DISCUSSION}

According to the Anova results, the substrates had a significant effect $(p<0.05 ; p<0.01)$ for all the evaluated parameters, except for the percentage of sprouts (Table 3 ).

The maximum sprouts percentages of the sugarcane mini-cuttings were observed at 14 DAP for all the substrates, except S5, for which the sprouting occurred at 20 DAP. At 35 DAP, no new shoots were observed (Figure 1). Similar results were reported by Gazola et al. (2017), who observed higher sprouting rates of sugarcane mini-cuttings close to 14 DAP.

There were no differences between the percentages of sprouts in response to the different substrates, and the average percentage of sprouts in all the substrates was $69.2 \%$ (Figure 2). It is possible to postulate that the physical conditions of density and porosity of the formulated substrates (Table 1) were suitable and promoted a good sprouting rate. According to Silva et al. (2010), under favorable

Table 3. Summary of the analysis of variance (Anova) of the parameters evaluated in pre-sprouted sugarcane seedlings grown on substrates with different proportions of decomposed babassu palm stem.

\begin{tabular}{|c|c|c|c|c|c|c|c|c|}
\hline \multirow{2}{*}{ Source } & \multicolumn{8}{|c|}{ Mean square } \\
\hline & Sprouting & $\mathrm{SD}$ & SL & $\mathrm{RL}$ & NL & SDM & $\mathrm{RDM}$ & TDM \\
\hline Substrate & $200.83^{\text {ns }}$ & $0.79 * *$ & $264.14 * *$ & $63.21 * *$ & $0.34 *$ & $0.18^{*}$ & $0.007 * *$ & $0.24 *$ \\
\hline Error & 145.83 & 0.16 & 47.64 & 10.36 & 0.09 & 0.05 & 0.001 & 0.06 \\
\hline $\mathrm{CV}(\%)$ & 17.46 & 7.63 & 11.08 & 16.84 & 7.67 & 24.94 & 14.340 & 22.17 \\
\hline
\end{tabular}

* Significant $(\mathrm{p}<0.05)$; ** significant $(\mathrm{p}<0.01)$; ${ }^{\text {ns }}$ not significant $(\mathrm{p}>0.05)$ by the F-test. SD: sprout diameter; SL: sprout length; RL: root length; NL: number of leaves; SDM: shoot dry mass; RDM: root dry mass; TDM: total dry mass. 
conditions of humidity and temperature, the buds present in the sugarcane mini-cuttings are activated, and their growth and development benefit from the nutritional reserves and growth regulators available in mini-cuttings. In another study, Gírio et al. (2015) found that the sprouting times, as well as the initial development of the seedlings, are directly influenced by the organic reserves present in the mini-cuttings.

With regard to sprout diameter, the best results were achieved with the use of S2, S3 and S4

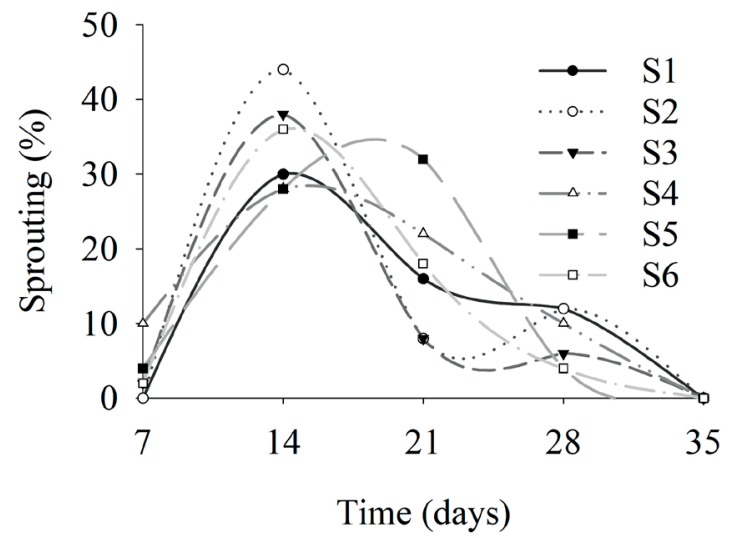

Figure 1. Sprouting time of sugarcane mini-cuttings grown on substrates with different proportions of decomposed babassu palm stem (DBPS). S1: $0 \%$ of DBPS $+100 \%$ of soil; S2: $20 \%$ of DBPS $+80 \%$ of soil; S3: $40 \%$ of DBPS $+60 \%$ of soil; S4: $60 \%$ of DBPS $+40 \%$ of soil; S5: $80 \%$ of DBPS $+20 \%$ of soil; S6: $100 \%$ of DBPS $+0 \%$ of soil.

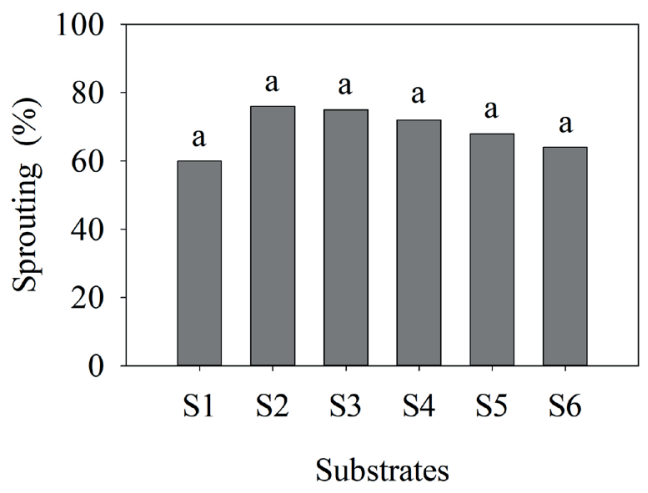

Figure 2. Percentage of sprouts of sugarcane mini-cuttings grown on substrates with different proportions of decomposed babassu palm stem (DBPS). S1: $0 \%$ of DBPS + $100 \%$ of soil; S2: $20 \%$ of DBPS $+80 \%$ of soil; S3: $40 \%$ of DBPS $+60 \%$ of soil; S4: $60 \%$ of DBPS + $40 \%$ of soil; S5: $80 \%$ of DBPS $+20 \%$ of soil; S6: $100 \%$ of DBPS $+0 \%$ of soil. (containing 20, 40 and $60 \%$ of DBPS, respectively), with average diameters of 5.6, 5.6 and $5.4 \mathrm{~mm}$, respectively (Figure 3A). This result suggests that both the physical (porosity and density) and chemical (nutrient) properties of these substrates fulfill the requirements of the seedlings up to 35 DAP. Regarding the sprout length, S2, S3, S4 and S5 showed average lengths of 71.1, 68.9, 68.2 and $63.7 \mathrm{~cm}$, respectively. Thus, the effect of the use of S2, S3, S4 and S5 on sprout length did not differ among these substrates, but differed significantly $(p>0.05)$ from those of the control and S6 (100\% of DBPS $+0 \%$ of soil) (Figure 3B). It is important to note that, in the initial phase, sprouting depends on both water and soil nutrients, as well as on the nutritional reserves stored in the mini-cuttings. This explains why the substrates containing the lowest proportions of DBPS and low concentrations of nutrients showed the best results.

In addition, the aforementioned results may be associated with high electrical conductivities (Table 2), which, according to Cruz et al. (2018), may cause a reduction in the absorption of water and nutrients, thereby affecting the growth of seedlings. Xavier et al. (2014) recommended that the salinity of the substrate for sugarcane should be in the range of $0.76-1.25 \mathrm{dS} \mathrm{m}^{-1}$. The S5 and S6 substrates (containing 80 and $100 \%$ of DBPS) had twice the electrical conductivity recommended for the sugarcane crop, what possibly contributed to the smaller diameter and length of the sprouts.

The addition of organic material such as DBPS to the soil as a conditioner improves the soil physical, chemical and water characteristics (Santos et al. 2020). However, when the quantity of organic material increases, it can considerably reduce the density of the substrate and, consequently, the contact of the roots with the particles of the substrate, thereby reducing the plant support and nutrient absorption (Costa et al. 2017). This was evident in the S6 substrate (Table 1), which had a global density value $\left(0.33 \mathrm{~g} \mathrm{~cm}^{-3}\right)$ below that recommended by Bunt (1974) for the cultivation of seedlings in containers. This was also reflected from the small root length of the seedlings grown in the $\mathrm{S} 6$ substrate (Figure 3C).

Although the S5 and S6 substrates showed high levels of macronutrients, they also showed a significant increase in electrical conductivity (Table 2), which may have negatively influenced the 

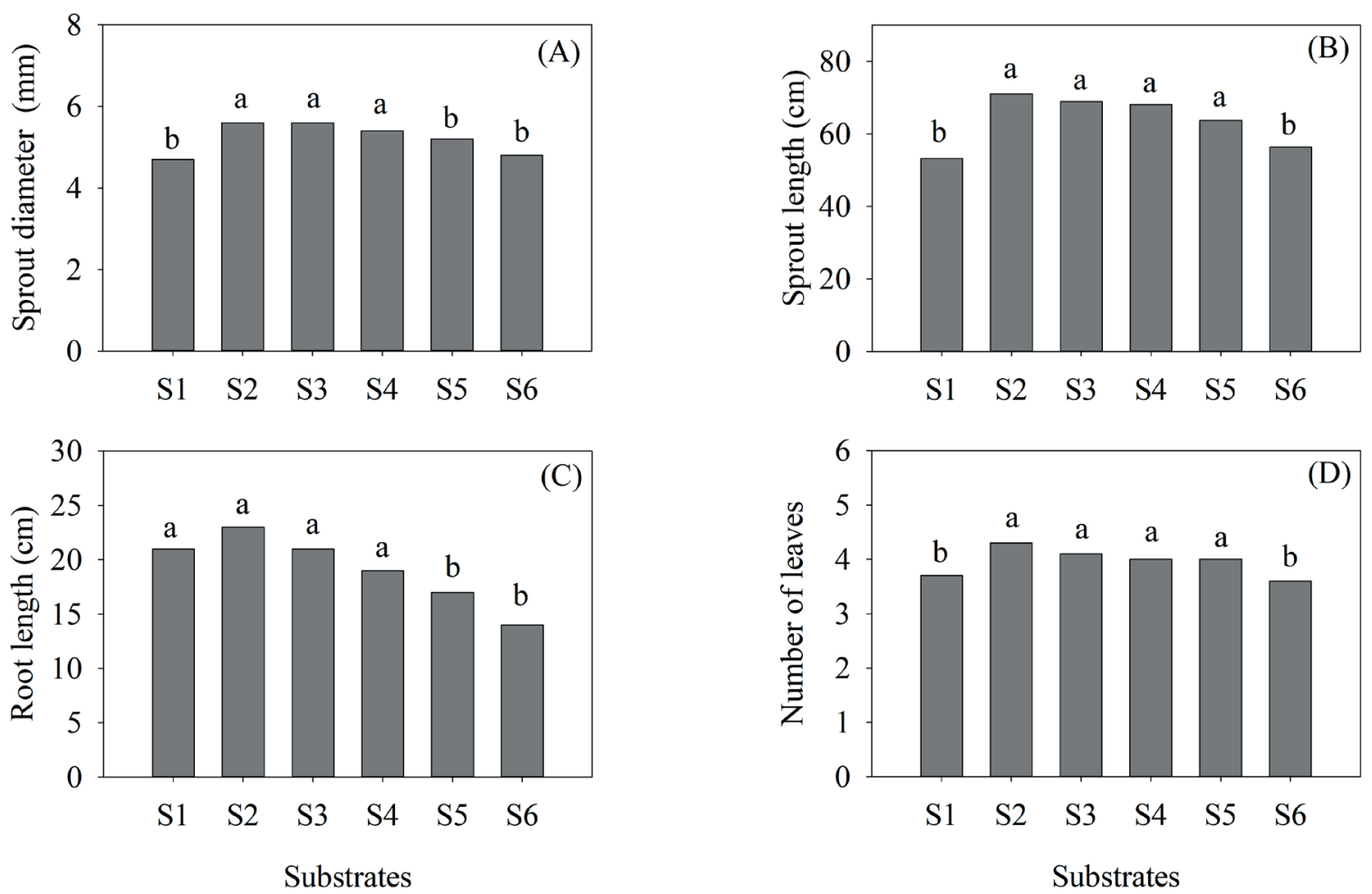

Figure 3. Sprout diameter, sprout length, root length and number of leaves of pre-sprouted sugarcane seedlings grown on substrates with different proportions of decomposed babassu palm stem (DBPS). S1: $0 \%$ of DBPS + 100 \% of soil; S2: $20 \%$ of DBPS $+80 \%$ of soil; S3: $40 \%$ of DBPS $+60 \%$ of soil; S4: $60 \%$ of DBPS $+40 \%$ of soil; S5: $80 \%$ of DBPS $+20 \%$ of soil; S6: $100 \%$ of DBPS $+0 \%$ of soil.

absorption of water and nutrients and affected the root expansion in the mini-cuttings.

With regard to the number of leaves, there was a significant difference in the effects of different substrates (Figure 3D). The S2, S3, S4 and S5 substrates showed better results, with 4.3, 4.1, 4.0 and 3.9 leaves, respectively, than the control and S6 (100\% of DBPS $+0 \%$ of soil). This result may be attributed to the better physical and chemical characteristics of these substrates than those of the control. The aforementioned substrates have lower global and particle densities, but higher total porosity, which can increase the storage and availability of water for the seedlings, than the control. In addition, the S2, S3, S4 and S5 substrates have higher amounts of nutrients than the control and lower electrical conductivity than the substrate with $100 \%$ of DBPS (S6).

A greater increase in the shoot dry mass was observed for S2 (20\% of DBPS $+80 \%$ of soil), with a shoot dry mass value of $40.5 \%$ more than the control; however, it was similar to those obtained for
S3 and S4 (Figure 4A). The intrinsic characteristics of the substrates, physical or chemical, may have influenced the quality of the seedlings, considering that the substrates S2, S3 and S4 present a greater balance among the concentration of nutrients, physical conditions (density and porosity) and electrical conductivity.

Further, the porosity of the substrates increased and the density decreased with the addition of DBPS, creating an environment that is considered suitable for the expansion of the root system. In this study, of all treatments, the treatment with the minimum percentage of DBPS ( $20 \%$ ) was sufficient to increase the shoot dry mass. This demonstrates the influence of the addition of organic material to the soil, as this treatment provides sufficient amounts of ionic loads, nutrients, water and oxygen to the seedlings (Soldateli et al. 2020).

The S2 substrate provided the highest root dry mass $(25.7 \%$ higher than the control); however, it was similar to the root dry mass achieved with the S3 substrate (Figure 4B). This indicates that the supply 

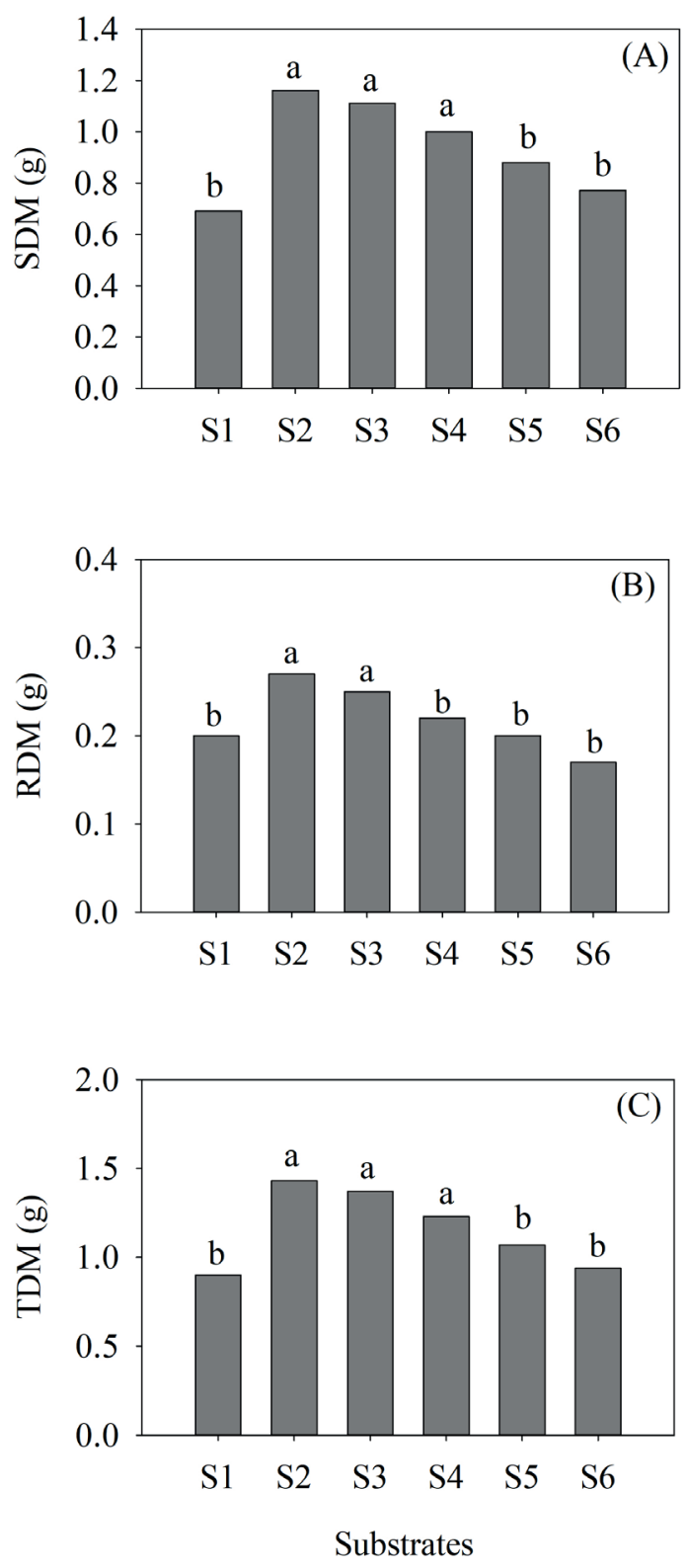

Figure 4. Shoot (SDM), root (RDM) and total (TDM) dry mass of pre-sprouted sugarcane seedlings grown on substrates with different proportions of decomposed babassu palm stem (DBPS). S1: $0 \%$ of DBPS + $100 \%$ of soil; S2: $20 \%$ of DBPS $+80 \%$ of soil; S3: $40 \%$ of DBPS $+60 \%$ of soil; S4: $60 \%$ of DBPS + $40 \%$ of soil; S5: $80 \%$ of DBPS $+20 \%$ of soil; S6: $100 \%$ of DBPS $+0 \%$ of soil.

of nutrients with $20 \%$ of DBPS in the substrate was more suitable for root development than that for the control, which provided a more acidic $\mathrm{pH}$ and probably less availability of phosphorous for the roots. Phosphorus is the nutrient responsible for root expansion, which contributes to a greater exploration and absorption of other nutrients in the substrate (Monteiro et al. 2018). In addition, S2 presented better results than substrates with higher percentages of DBPS (S4, S5 and S6), which showed a higher electrical conductivity.

In addition to the lower substrate electrical conductivity, it is possible that the relationship between nutrients and physical conditions influenced the root dry mass value. According to Lima et al. (2008), it is complex to define the factors responsible for the increase in mass or root growth. However, the availability of water, nutrients, oxygen, plant hormones, carbohydrate supply and their reserves in the roots and shoots of the plant certainly play a role in this.

The total dry mass was influenced by the different proportions of DBPS in the substrates. The highest values were observed for S2, S3 and S4 (Figure 4C), and the values did not differ among themselves. This result may be attributed to the values of shoot and root dry mass, considering the association between these variables (Table 4).

The substrate with $20 \%$ of DBPS $+80 \%$ of soil (S2) was sufficient to promote an increase in the sprout diameter, root length, number of leaves and total, shoot and root dry mass. This is due to the better physical and chemical characteristics, such as lower density, higher porosity, higher $\mathrm{pH}$ and higher nutrient concentration in the $\mathrm{S} 2$ substrate than in the control.

The Pearson's correlation analysis ( $\mathrm{r}$ ) showed a significant positive linear correlation $(\mathrm{p}<0.01)$ among all the evaluated parameters (Table 4). According to the classification adopted by Gavioli et al. (2019), sprouting has a moderate correlation $(0.4<\mathrm{r} \leq 0.6)$ with root length $(0.51)$ and a strong correlation $(0.6<\mathrm{r} \leq 0.8)$ with the other variables. Regarding the seedling quality parameters, very strong correlations $(0.8<\mathrm{r} \leq 1)$ were observed between the sprout diameter and length $(\mathrm{r}=0.82)$, sprout diameter and number of leaves $(r=0.85)$, and bud length and number of leaves $(r=0.81)$. The total dry mass, which is considered as one of the most important parameters for evaluating the seedling quality, showed a very strong correlation $(0.8<\mathrm{r} \leq 1)$ with the sprout diameter $(\mathrm{r}=0.81)$, shoot dry mass $(\mathrm{r}=1)$ and root dry mass $(\mathrm{r}=0.85)$. This implies that an effect on any of the seedling quality parameters may negatively affect the other parameters, as they are positively correlated. 
Table 4. Pearson's correlation for sprouting and quality parameters of pre-sprouted sugarcane seedlings grown on substrates with different proportions of decomposed babassu palm stem.

\begin{tabular}{lclllllll}
\hline & Sprouting & SD & SL & RL & NL & SDM & RDM & TDM \\
\hline Sprouting & 1 & & & & & & & \\
SD & $0.72^{* *}$ & 1 & & & & & & \\
SL & $0.78^{* *}$ & $0.82^{* *}$ & 1 & & & & & \\
RL & $0.51^{* *}$ & $0.57^{* *}$ & $0.64^{* *}$ & 1 & & & & \\
NL & $0.67^{* *}$ & $0.85^{* *}$ & $0.81^{* *}$ & $0.58^{* *}$ & 1 & & & \\
SDM & $0.76^{* *}$ & $0.80^{* *}$ & $0.79^{* *}$ & $0.56^{* *}$ & $0.64^{* *}$ & 1 & & \\
RDM & $0.69^{* *}$ & $0.75^{* *}$ & $0.77^{* *}$ & $0.61^{* *}$ & $0.71^{* *}$ & $0.80^{* *}$ & 1 & \\
TDM & $0.77^{* *}$ & $0.81^{* *}$ & $0.80^{* *}$ & $0.58^{* *}$ & $0.67^{* *}$ & $1.00^{* *}$ & $0.85^{* *}$ & 1 \\
\hline
\end{tabular}

** Significant $(\mathrm{p}<0.01)$. SD: sprout diameter; SL: sprout length; RL: root length; NL: number of leaves; SDM: shoot dry mass; RDM: root dry mass; TDM: total dry mass.

\section{CONCLUSIONS}

1. The substrates formulated with decomposed babassu palm stem (DBPS) and dystrophic Yellow Latosol in the proportions of 1:4 (v/v) and 2:3 (v/v) provided a greater sprouting up to 14 days after planting (DAP), as well as a greater development of shoots and roots up to $35 \mathrm{DAP}$, in pre-sprouted sugarcane seedlings;

3. The use of substrate formulated with $20 \%$ of DBPS and $80 \%$ of soil, with physical and chemical characteristics as described in this study, can be recommend, because such a substrate provides a favorable environment for the growth and development of pre-sprouted sugarcane seedlings for up to 35 days after sowing, in addition to being more economically viable;

3. Substrates with proportions of DBPS higher than $60 \%$ reduce the quality of pre-sprouted sugarcane seedlings.

\section{REFERENCES}

ANDRADE, H. A. F. de; COSTA, N. A.; CORDEIRO, K. V.; OLIVEIRA-NETO, E. D. de; ALBANO, F. G.; SILVA-MATOS, R. R. S. da. Caule decomposto de babaçu (Attlea speciosa Mart.) como substrato para produção de mudas de melancieira. Cultura Agronômica, v. 26, n. 3, p. 406-416, 2017.

AQUINO, G. S. de; SANTOS, J. G. S. dos.; DINIZ, T. G.; MEDINA, C. de C.; ROSSETO, R.; MOREIRA, A. Development of pre-sprouted seedlings (PSS) of sugarcane under different amounts of filter cake and application modes. Semina, v. 39, n. 5, p. 1899-1908, 2018.

BRASIL. Ministério da Agricultura, Pecuária e Abastecimento. Instrução normativa SDA n ${ }^{\circ}$ 17, de 21 de maio 2007. Métodos para análise de substratos para plantas e condicionadores de solos. Diário Oficial da República Federativa do Brasil: seção 1, Brasília, DF, n. 99, p. 8, 24 maio 2007. Available at: https://www.gov.br/agricultura/ pt-br/assuntos/insumos-agropecuarios/insumos-agricolas/ fertilizantes/legislacao/in-17-de-21-05-2007-aprovametodo-substrato.pdf. Access on: 16 Apr. 2020.

BUNT, A. C. Some physical and chemical characteristics of loamless pot-plant substrates and their relation to plant growth. Acta Horticulturae, v. 37, n. 1, p. 1954-1965, 1974.

COMPANHIA NACIONAL DE ABASTECIMENTO (Conab). Acompanhamento da safra brasileira de canade-açúcar, safra 2019/20.2020. Available at: www.conab. gov.br. Access on: 27 Feb. 2021.

CORDEIRO, K. V.; ANDRADE, H. A. F.; OLIVEIRANETO, E. D. de; COSTA, N. A.; ROCHA, B. R. dos S.; PONTES, S. F.; MARZULLO, Y. O. T.; PINTO, F. E. do N.; MACHADO, N. A. F.; SILVA-MATOS, R. R. S. da. New substrates based on decomposed babassu (Attalea speciosa Mart.) stem in the production of melon seedlings. Journal of Experimental Agriculture International, v. 26, n. 1, p. 1-7, 2018.

CORDEIRO, K. V.; COSTA, N. A.; ANDRADE, H. A. F. de; OLIVEIRA-NETO, E. D. de; ROCHA, B. R. dos S.; FARIAS MACHADO, N. A.; ALBANO, F. G.; FURTADO, M. B.; SILVA-MATOS, R. R. S. Inclusion of babassu decomposed stem substrates on the pattern of the vegetative growth of passion fruit seedlings. Communications in Soil Science and Plant Analysis, v. 50, n. 21, p. 2777-2786, 2019.

COSTA, J.C.F. da; MENDONÇA, R. M.N.; FERNANDES, L. F.; OLIVEIRA, F. P. de; SANTOS, D. Caracterização física de substratos orgânicos para o enraizamento de estacas de goiabeira. Revista Brasileira de Agropecuária Sustentável, v. 7, n. 2, p. 16-23, 2017.

CRUZ, F. J. R.; FERREIRA JÚNIOR, D. da C.; SANTOS, D. M. M. Low salt stress affects physiological parameters and sugarcane plant growth. Australian Journal of Crop Science, v. 12, n. 8, p. 1272-1279, 2018. 
FERREIRA, D. F. Sisvar: a computer statistical analysis system. Ciência e Agrotecnologia, v. 35, n. 6, p. 10391042, 2011.

GAVIOLI, A.; SOUZA, E. G. de; BAZZI, C. L.; SCHENATTO, K.; BETZEK, N. M. Identification of management zones in precision agriculture: an evaluation of alternative cluster analysis methods. Biosystems Engineering, v. 181, n. 1, p. 86-102, 2019.

GAZOLA, T.; CIPOLA FILHO, M. L.; FRANCO JÚNIOR, N. C. Avaliação de mudas pré-brotadas de cana-de-açúcar provenientes de substratos submetidos a adubação química e orgânica. Científica, v. 45, n. 3, p. 300-306, 2017.

GÍRIO, L. A. da S.; DIAS, F. L. F.; REIS, V. M.; URQUIAGA, S.; SCHULTZ, N.; BOLONHEZI, D.; MUTTON, M. A. Bactérias promotoras de crescimento e adubação nitrogenada no crescimento inicial de canade-açúcar proveniente de mudas pré-brotadas. Pesquisa Agropecuária Brasileira, v. 50, n. 1, p. 33-43, 2015.

JAIN, R.; SOLOMON, S.; SHRIVASTAVA, A. K.; CHANDRA, A. Sugarcane bud chips: a promising seed material. Sugar Tech, v. 12, n. 1, p. 67-69, 2010.

LANDELL, M. G. A.; CAMPANA, M. P.; FIGUEIREDO, P. Sistema de multiplicação de cana-de-açúcar com uso de mudas pré-brotadas (MPB), oriundas de gemas individualizadas. Campinas: Instituto Agronômico, 2012. (Documento, n. 109).

LIMA, L. S. H.; FRANCO, E. T. H.; SCHUMACHER, M. V. Crescimento de mudas de Euterpe edulis Martius em resposta a diferentes doses de fósforo. Ciência Florestal, v. 18, n. 4, p. 461-470, 2008.

MACAN, N. P. F.; FERRAREZI, R. S.; MATSURA, E. E. Fertilizer recommendations for sugarcane presprouted seedling production in ebb-and-flow subirrigation benches. Sugar Tech, v. 22, n. 6, p. 978-986, 2020.

MARTÍNI, A. F.; VALANI, G. P.; BOSCHI, R. S.; BOVI, R. C.; SILVA, L. F. S.; COOPER, M. Is soil quality a concern in sugarcane cultivation?: a bibliometric review. Soil and Tillage Research, v. 204, e104751, 2020.

MAY, A.; RAMOS, N. P. Uso de gemas individualizadas de cana-de-açúcar para a produção de mudas. Jaguariúna: Embrapa, 2019. (Circular técnica, n. 19).

MONTEIRO, R. S.; OLIVEIRA, V. E. A.; MALTA, A. O.; PEREIRA, E. W.; SILVA, J. A.; MALTA, A. O. Produção de mudas de cafeeiro em função da época e da adubação fosfatada. Revista PesquisAgro, v. 1, n. 1, p. 28-38, 2018.

SANTOS, H. G.; JACOMINE, P. K. T.; ANJOS, L. H. C.; OLIVEIRA, V. A.; LUMBRERAS, J. F.; COELHO,
M. R.; ALMEIDA, J. A.; CUNHA, T. J. F.; OLIVEIRA, J. B. Sistema brasileiro de classificação de solos. 3. ed. Brasília, DF: Embrapa, 2013.

SANTOS, L. S.; BRAGA, N. C. C.; RODRIGUES, T. M.; RUBIO NETO, A.; BRITO, M. F.; SEVERIANO, E. da C. Pre-sprouted seedlings of sugarcane using sugarcane industry by-products as substrate. Sugar Tech, v. 22, n. 1, p. 675-685, 2020.

SCHMITZ, J. A. K.; SOUZA, P. V. D.; KAMPF, A. N. Propriedades químicas e físicas de substratos de origem mineral e orgânica para cultivo de mudas em recipientes. Ciência Rural, v. 32, n. 6, p. 937-944, 2002.

SILVA, M. A.; SANTOS, C. M.; ARANTES, M. T.; PINCELLI, R. P. Fenologia da cana-de-açúcar. In: CRUSCIOL, C. A. C.; SILVA, M. de A.; ROSSETTO, R.; SORATTO, R. P. (ed.). Tópicos em ecofisiologia da cana-de-açúcar. Botucatu: Fundação de Estudos e Pesquisas Agrícolas e Florestais, 2010. p. 8-21.

SILVA, M. T. da; MARTINAZZO, R.; SILVA, S. D. A.; BAMBERG, A. L.; STUMPF, L.; FERMINO, M. H.; KOHLER, T. W.; MATOSO, E. S.; VALGAS, R. A. Innovative substrates for sugarcane seedling production: sewage sludges and rice husk ash in a waste-to-product strategy. Industrial Crops \& Products, v. 157, e112812, 2020.

SILVA, S. D. dos A. e; MONTERO, C. R. S.; TATTO, F. R.; SIMOM, E. D. T.; ANTUNES, W. R. Produção de mudas. In: SILVA, S. D. dos A. e; MONTERO, C. R. S.; SANTOS, R. C. dos; NAVA, D. E.; GOMES, C. B.; ALMEIDA, I. R. de (ed.). Sistema de produção de cana-de-açúcar no Rio Grande do Sul. Pelotas: Embrapa Clima Temperado, 2016. p. 132-150.

SOLDATELI, F. J.; BATISTA, C. B.; GODOY, F.; MELLO, A. C.; SOARES, F. S.; BERGMANN, M. D.; ETHUR, L. Z. Crescimento e produtividade de cultivares de tomate cereja utilizando substratos de base ecológica. Colloquium Agrariae, v. 16, n. 1, p. 1-10, 2020.

XAVIER, M. A.; LANDELL, M. G. A.; CAMPANA, M. P.; FIGUEIREDO, P.; MENDONÇA, J. R.; DINARDOMIRANDA, L. L.; SCARPARI, M. S.; GARCIA, J. C.; ANJOS, I. A.; AZANIA, C. A. M.; BRANCALIÃO, S. R.; KANTHACK, R. A. D.; AFERRI, G.; SILVA, D. N.; BIDÓIA, M. A. P.; CAMPOS, M. F.; PERRUCO, D.; MATSUO, R. S.; NEVES, J. C. T.; CASSANELI JUNIOR, J. R.; PERRUCO, L.; PETRI, R. H.; SILVA, T. N.; SILVA, V. H. P.; THOMAZINHO JUNIOR, J. R.; MIGUEL, P. E. M.; LORENZATO, C. M. Fatores de desuniformidade e kit de pré-brotação IAC para sistema de multiplicação de cana-de-açúcar: mudas pré-brotadas (MPB). Campinas: Instituto Agronômico, 2014. (Documentos, n. 113). 